\title{
24 Tirtha's of Ramanatha Swamy Temple, Rameswaram
}

\section{OPEN ACCESS}

Volume: 7

Issue: 2

Month: October

Year: 2019

P-ISSN: 2321-788X

E-ISSN: 2582-0397

Received: 16.09.2019

Accepted: 28.09.2019

Published: 01.10.2019

Citation:

Ramamoorthy, G., and J. Albaris. "24 Tirtha's of Ramanatha Swamy Temple, Rameswaram." Shanlax International Journal of Arts, Science and Humanities, vol. 7, no. 2, 2019, pp. 95-97.

DOI:

https://doi.org/10.34293/ sijash.v7i2.816

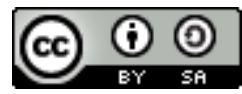

This work is licensed under a Creative Commons Attribution-ShareAlike 4.0 International License

\author{
G. Ramamoorthy \\ PhD. Research Scholar (Full-Time), Post Graduate and Research Department of History \\ Alagappa Government Arts College, Karaikudi, Tamil Nadu, India
}

\section{J. Albaris}

Associate Professor, Post Graduate and Research Department of History

Alagappa Government Arts College, Karaikudi, Tamil Nadu, India

\begin{abstract}
We know Ramayana and Ramesawaram, the memorable temple located at the tip of Indian Point in Tamil Nadu. It is the most important visit in the Hindu Religion and through the year tourist multitude the place to take a bath in the famous "Tirthams" of Rameswaram. Ramanathaswamy Temple is a Hindu temple enthusiastic to the god Shiva located on Rameswaram island in the state of Tamil Nadu, India. Rameswaram Temple Tirthas are the holy wells situated inside the Rameswaram Temple in Tamilnadu, India. There are sixty-four Tirthas (holy water bodies) in and around the island of Rameswaram. According to Skanda Purana, 24 Tirthas in Rameswaram are important and taking snan (bathing) in them are considered equivalent to penance. Twenty-Two Thirthas are inside Ramanatha Swami Temple.
\end{abstract}

Keywords: Tirthams, Hindu temple, Rameswaram, Pilgrimage, Jyotirlinga, Nayanars.

\section{Introduction}

We know Ramayana and Ramesawaram, the memorable temple located at the tip of Indian Point in Tamil Nadu. It is one between the 12 Jyotirlingas and one of the vital part of "Char Dham Yatra" ( Pilgrimage) in Hindu belief. Every tiny part of Rameswaram is related with Ramayana; It is whispered that Lord Rama has adored Shiva here, it is one domicile in India where both Shaivism and Vaishnavism adoration. It is the most important visit in the Hindu Religion and through the year tourist multitude the place to take a bath in the famous "Tirthams" of Rameswaram. These Tirthams' regardless of the year, weather conditions are everlastingly full. And affording to the "Skanda puranamam" there are 64 Tirthams' in and near Rameswaram, but 24 of them are the greatest important of them which give forfeiture to the man from his iniquities. Among the 24 Tirtham's two are separate the Ramanatha Swamy temple, and the respite 22 is inside the premises. It is believed that the 22 wells characterize the arrows in Lord Rama's Quire. Let to distinguish some more about the temple and the Secretive Tirthams' of Rameswaram.

\section{Temple}

Ramanathaswamy Temple is a Hindu temple enthusiastic to the god Shiva located on Rameswaram island in the state of Tamil Nadu, India. One of the twelve Jyotirlinga temples. It is single of the 274 Paadal Petra Sthalams, where the three of the most respected Nayanars (Saivite saints), Appar, Sundarar, and Tirugnana Sambandar, have overvalued the temple with their songs. 
The temple was prolonged during the 12th century by Pandya Empire, and its principal shrines sanctum was renewed by Jeyaveera Cinkaiariyan and his successor Gunaveera Cinkaiariyan of the Jaffna kingdom. The temple has the longest corridor among all Hindu temples in India. The temple is located in Rameswaram careful a sanctified pilgrimage site for Shaivites, Vaishnavites, and Smarthas. The presiding deity, the Lingam of Ramanathaswamy (Shiva), is thought to have been traditional and worshipped by Rama, an avatar of the god Vishnu, to absolve the sins created during the Ramayana combat at Sri Lanka.

The temple and the island of Rameswaram have learned this name because, Lord Rama worshipped Lord Shiva, the God of Gods here on reoccurrence from Sri Lanka. According to legend, after killing Ravana Lord Rama reimbursed with his consort Goddess Seetha to India first stepping on the shores of Rameswaram. To expiate the "dosha" of killing a brahmin, Lord Rama wanted to offer worship to Lord Shiva. Since there was no shrine in the island had despatched Sri Hauman to Kailash to bring an idol of Lord Shiva. Between 1897 and 1904, the ALAR family of Devakottai completed the imposing eastern tower of nine tiers 126 feet in height from Thiruppani funds. The Temple has the world's largest Corridor.

\section{Tirtha's of Rameswaram}

"Rameswaram Temple Tirthas are the holy wells situated inside the Rameswaram Temple in Tamilnadu, India. There are sixty-four Tīrthas (holy water bodies) in and around the island of Rameswaram. According to Skanda Purana, 24 Tirthas in Rameswaram are important and taking snan (bathing) in them are considered equivalent to penance. Twenty-Two Thirthas are inside Ramanatha Swami Temple."

1. Agni Theertham - It is situated in the seashore east of Ramanathaswamy Temple.

2. Setu Teertham - It is situated at Dhanushkodi Other 22 Tirthas privileged the temple.

3. Mahalakshmi Tirtha - according to the legend King Yudhistra removed bath here and became rich.

4. Savithri Tirtha - It is supposed that Kashyapa became rid of his curse after charming a holy dip in this theertham.
5. Gayathri Tirtha - According to the legend King Kasibar had got rid of his swearword after taking an immersion in this Tirtha.

6. Saraswathi Tirtha - King Kasibar got rid of his obscenity after the Gayatri Tirtha

7. Sethu Madhava Tirtha - If one takes a bath in this well it is believed that the persons will be blessed by Mahalakshmi and get purified of impure thoughts.

8. Gandhamadana Tirtha - according to the state Purana if one takes a bath in this well he will get rid of poverty.

9. Kavatcha Tirtha - this Tirtha assistances one get rid of sins and will not go to the underworld

10. Gavaya Tirtha - According to the Purana's dip in this well will get housing under Karpaga Virutchaga or Kalpa Vriksha tree.

11. Nala Theertham - the person who takes involvement in this Tirtha will be blessed by Lord Surya and reach paradise.

12. Neela Tirtha - According to the Skanda Purana, taking a bath in this well is equivalent to having performed various yagnas and will obtain Agni Yoga

13. Sanku Tirtha - It is believed that Sage Vatsanabha got rid of his sin of ungratefulness by taking a bath in this Tirtha.

14. Chakkara Tirtha - According to the legend, the Sun God had got his hand turned golden after bathing in this Tirtha.

15. Brahmahathi Vimochana Tirtha - Bathing in this Tirtha will help to get rid of Brahma Hathya Dosham

16. Sooriya Tirtha - According to the puran's bathing in this temple helps to obtain information of the past present and the future

17. Chandra Tirtha - bathing in this Tirtha too serves to obtain knowledge of the past present and the future

18. Ganga Tirtha-According to the stala puranmam, Gananasuruthi Rajah achieved wisdom after taking a bath in this well.

19. Yamuna Tirtha - Gananasuruthi Rajah attained wisdom

20. Gaya Tirtha-Gananasuruthi Rajah attained wisdom

21. Siva Tirtha - Accomplishment of Bhaira Brahmahathi 
22. Sadyamirtha Tirtha - According to the myth Emperor Bururoonu got rid of his profanity after taking a bath in this Tirtha.

23. Sarva Tirtha - It is believed that Sutharishna got prospered after getting rid of his blindness (from birth) and illness after taking a bath in this Tirtha.

24. Kodi Theertham - According to the Skanada Purana, Lord Sree Krishna got rid of his sin of killing Kamsa here after taking a bath in this Tirtham.

\section{Conclusion}

The temple is one of the most divine Hindu Char Dham (four divine sites) sites comprising Badrinath, Puriand Dwarka. However the origins are not known, the Advaita school of Hinduism documented by Sankaracharya, who created Hindu monastic administrations across India, traits the source of Char Dham to the seer. The four friaries lie across the four corners of India, and their attendant temples are Badrinath Temple at Badrinath in the North, Jagannath Temple at Puri in the East, Dwarakadheesh Temple at Dwarka in the West and Ramanathaswamy Temple at Rameswaram in the South.

\section{References}

Loganathan, SP. "Shortage of Priests at Rameswaram Temple.” Deccan Chronicle, 2012.

Murali, JC. Tamizhaga Sivatalangal, Chatura Padipakkam, Chennai, 2000.

Seturaman, K. Rameswaram Koil. J. J. Publications, Madurai, 2001.

Singh, S. South India (Lonely Planet Regional Guide) (5th ed.). Lonely Planet, 2009.

Ramamurthy, T. Engineering in Rocks for Slopes Foundations and Tunnels (2bd ed.). PHI Learning Private Limited, New Delhi, 2007.

Thangaraj, M. Tamil Nadu: An Unfinished Task. SAGE, 2003, p. 170.

Venugopalam, R. Meditation: Any Time Anywhere, B. Jain Publishers (P) Ltd, New Delhi, 2003.

\section{Author Details}

G.Ramamoorthy, PhD. Research Scholar, (Full-Time), Post Graduate and Research, Department of History, Alagappa Government Arts College, Karaikudi, Tamil Nadu, India, Email ID: journalkkdi2019@gmail.com.

Dr.J.Albaris, Associate Professor, Post Graduate and Research, Department of History, Alagappa Government Arts College, Karaikudi, Tamil Nadu, India. 